\title{
The Spirit of the Sword and Spear
}

\author{
Mark Pearce
}

From the Norse sagas or the Arthurian cycles, we are used to the concept that the warrior's weapon has an identity, a name. In this article I shall ask whether some prehistoric weapons also had an identity. Using case studies of La Tène swords, early Iron Age central and southern Italian spearheads and middle and late Bronze Age type Boiu and type Sauerbrunn swords, I shall argue that prehistoric weapons could indeed have an identity and that this has important implications for their biographies, suggesting that they may have been conserved as heirlooms or exchanged as prestige gifts for much longer than is generally assumed, which in turn impacts our understanding of the deposition of weapons in tombs, where they may have had a 'guardian spirit' function.

There are many ways in which we can approach prehistoric weapons (Pearce 2007): we can study them typologically, to see how their form is related to the sequence of types, and we can also use that information to date them, assigning them to chronological horizons. We can examine them functionally, and try to assess how effective they will have been as weapons, or perhaps as parade paraphernalia rather than utilitarian equipment. We can look at use wear and try to reconstruct how and for what purpose they were used. Or we can examine them from a metallurgical point of view, looking at how they were made, how efficient their edges and points may be, or perhaps through chemical analysis trying to reconstruct their provenance. More recently other ways of looking at material culture have come to the fore, and so for example we might examine the 'biography' of the artefact.

The biographical approach, which follows the life cycle of an artefact, was proposed by Igor Kopytoff, who emphasized that such a biography 'would look at ... [an object] as a culturally constituted entity, endowed with culturally specific meanings, and classified and reclassified into culturally constituted categories' (Kopytoff 1986, 68); the significance of artefacts thus changes through time in relation to their context. Gosden and Marshall $(1999,170)$ add that '[n]ot only do objects change through their existence, but they often have the capability of accumulating histories, so that the present significance of an object derives from the persons and events to which it is connected'. They illustrate this point through Trobriand kula exchange.

In this article I shall take an approach which is related to this latter trend, but rather than try to examine the biography of some prehistoric swords and spears, I want to pose the question: was an identity attributed to some prehistoric weapons? By using the term 'identity' I do not mean to argue that prehistoric weapons were regarded as equivalent to humans, but rather that they had some sort of spiritual persona (which may or may not have been nuanced as regards aspects such as gender or ethnicity) with its own specific agency, believed to have its own intention and volition. This might have been perceived as some sort of in-dwelling spirit.

In order to answer the question as to whether an identity was attributed to some weapons we need to ask how we can know when something has been attributed an identity. I would argue that one way is where it has been assigned a name, because we give names to things to which we attribute a measure of personhood, and therefore agency (Dobres 2000). For example, we give names to pets, but not necessarily to farm animals. Another way that we attribute an identity, or some sort of personhood, to an object is by giving it eyes, a face or an anthropomorphic form.

On the basis of these two observations, I shall use some different classes of evidence to argue that prehistoric weapons could indeed have identities. First I shall use the comparative method, looking at both 
medieval artefacts and literary sources, myth and epic, and then secondly, I shall work backwards in time, looking at particular examples of swords and spears first from the Iron Age and then from the Bronze Age.

\section{Weapon identities}

The idea that weapons can have names and supernatural powers and consequently agency is a concept that occurs in medieval epic, such as the twelfth-century Chanson de Roland (171, 2300 to 173, 2344: Roland's sword Durendal could not be broken), and in the Arthurian cycles. Thomas Malory's Morte d'Arthur, which was written about 1470 (Vinaver 1971, vi), narrates the story of King Arthur's special sword named Excalibur, which was given to him by the Lady of the Lake (Book 1, 25). This sword was so special that, on his death bed, Arthur instructed one of his knights, Sir Bedivere, to return it to the waters (Book 21, 5). The story was used as an illustration of prehistoric ritual deposition in water by Richard Bradley (1990, 1-3), but it also attests to the concepts that weapons may have names and magical properties and capacities.

Other weapons in myth cycles or epics could also have names, and therefore identities (Ellis Davidson 1962, 82, 102, 151, 177; Barnes 1972; 1982; Kristiansen 2002, 329-30): for example, named swords appear in the Old English poem, Beowulf, in which Beowulf kills Grendel's mother with a precious sword called Hrunting lent him by Unferth (Beowulf 1455-64), and also in the Völsunga saga, where Sigurdur Fåvnesbane's sword is called Gramr ('wrath': chap. 15) and Fáfnir the dragon's sword has the name Hrotti (perhaps translatable as 'the audacious one': chap. 19). Indeed, swords are named in all types of sagas, although infrequently, and about 100 sword-names are known (Barnes 1972, col. 544). Barnes notes that not all swords had names and that it seems to have been the custom to give a sword a name only when it had proved itself in one way or another (1972, cols. 544-5). He groups the sword names in a number of categories (Barnes 1972, cols. 545-6):

1. a personal name in the genitive form with the suffix -nautr 'gift' (earlier owner, giver; sometimes this is ironic, when the personal name is that of the original owner who was killed by the subsequent owner)

2. the nickname of a (previous) owner

3. the name (or derived from the name) of the smith who made it

4. the general visual appearance of the sword (e.g. Ryðfrakki, the red-coated (i.e. rusty) weapon)

5. swords with particularly splendid fittings or decoration (e.g. 'Goldenhilt')
6. general characteristics of the sword (e.g. 'Long')

7. desirable or intended characteristics of the sword (e.g. 'Bloodrush')

8. the sound of the sword

9. the sharpness of the sword, with reference to particular episodes (e.g. 'Quern-biter')

10. words for snakes, wolves and fire (possibly derived from poetic language in which swords are compared to them because of their similar appearance) 11. abstract concepts (e.g. 'Agony', 'Honour').

$\mathrm{He}$ also notes that some scholars suggest that some swords (such as Flæmingr) are named after Germanic tribes or ancestral groups, but that other explanations are possible.

We may usefully distinguish two general classes of name in Barnes's rather nuanced classification: first, names which establish the ownership of the sword (category 1) or which establish the sword's previous biography (categories 2 and 3), and second, names that relate to the qualities of the sword itself (categories 4-11) (cf. Ellis Davidson 1962, 177).

Where ownership is denoted, the sword name may not be intended to indicate a specific identity (as also today we write our names on objects such as books), but Barnes's classification draws our attention to the fact that some swords, in addition to having names, could also have complex biographies in which, for example, whom they belonged to, or had belonged to, or who had made them was important (Barnes's categories 2 and 3; cf. Ellis Davidson 1962, 169-75). The importance of biographies can be illustrated by two examples from the Norse (i.e. Norwegian and Icelandic) sagas: Sigurdur's Gramr was reforged from the pieces of his father Sigmund's sword by the smith, Regin (Völsunga saga, 15), and in the saga of Gísli Súrsson, the sword called Grásiðða, which means ‘Greysided one', was broken and then re-forged as a spear (Gísla saga Súrssonar 7: Barnes 1972, col. 547). In these instances, the name itself does not indicate anything of their biography but in other cases it could do so, as in the spear Selshefnir ('the revenger of Sel') or the shield Viljálmsgørð ('Viljálmr's handiwork') (Barnes 1982, col. 283).

The sword name Curtana, or its variant Curtein, is first mentioned in the thirteenth century as denoting one of the swords carried at English coronations. It was supposed to be the sword of Ogier the Dane, one of Charlemagne's knights in the Chanson de Roland, a weapon with a broken blade which had originally belonged to Tristram (Ditmas 1966). Most of the coronation regalia were destroyed after the English Civil War during the Commonwealth, and so Curtana, (also called the 'Sword of Mercy') was remade in the seventeenth century with a broken-off point for the 
coronation of Charles II and this sword is still used in coronations and investitures by the British monarch (Holmes \& Sitwell 1972, 12-13). The name thus illustrates a long and romantic (but fictitious) biography.

As well as swords, Barnes tells us that axes, spears, arrows, shields, helmets and mail-coats all may have Norse weapon names. For example in the Edda, Odin's spear Gungnir ('Swayer?'), the helmet Hildigöltr or Hildisvín ('Battle-boar, -pig'), or Thor's hammer Mjöllnir ('Crusher') (Barnes 1982, cols. 282-5).

These names are found in literature, but some of the events described may have had a historical basis. Indeed, sometimes weapons with names belonged to actual historical figures: St Olaf's axe was named after the Norse goddess of the underworld, Hel, and Harald hard-ruler's mail-coat was called Emma, whilst an axe called Kerling ('Old Woman') is mentioned in a diploma (Barnes 1982, col. 282). Further confirmation is given by exceptional archaeological finds. In Nordic Europe the oldest instance of a weapon name is raunijar, or 'Tester', which is written in runes on the spearhead from Øvre Stabu in Norway, dating to about AD 150-200 (Barnes 1972, col. 544; Krause 1966, $75-6, n .31)$. There are other early examples of names on spearheads (Krause 1966, 76-82, n. 32 - Dahmsdorf, Brandenburg, Germany; n. 33 - Kovel', Volyns'ka oblast', Ukraine; n. 34 - Moos, Gotland, Sweden; and n. 35 - Rozwadów, Stalowa Wola, Poland; cf. Barnes 1972, col. 544) and on swords from Danish bog-finds (Ellis Davidson 1962, 42-3, e.g. at Nydam Mose, Sønderborg, Denmark).

Similar examples of named weapons are found in medieval Ireland. The early twelfth-century Irish text Scéla Conchoboir maic Nessa (Tidings of Conchobor mac Nessa) contains a list of shields and swords that were kept in King Conchobor's house - these are identified by both the name of the weapon and the name of its owner (Kinsella 1969, 5).

This assigning of a name or a biography suggests the attribution of an identity to weapons. This is illustrated by the observation that in the early thirteenth-century, Middle High German epic the Nibelungenlied, Siegfried's sword, Balmung, is almost a character in the poem; Hatto $(1969,401)$ comments that 'in heroic poetry swords are persons', that is they were perceived of as having their own identity and agency. Thus we may conclude from all these examples that in the Middle Ages of northern Europe weapons could have an identity.

\section{Did prehistoric weapons have identities?}

Having established that weapons had identities in early myth and epic, the question we must ask is: did weapons have identities in prehistory also? The extent to which the various stories of the Ulster Cycle actually reflect the realities of pre-Christian Ireland is the subject of heated debate, the traditional view being that they describe episodes from the time of Christ, during the Iron Age of Ireland (Jackson 1964, 43-6; Kinsella 1969, ix). Jackson (1964) saw them as a 'window on the Iron Age' (as the title of his book proclaims) while Aitchison concludes that 'early Irish epic literature does not constitute a legitimate source for the study of pagan Celtic society' (Aitchison 1987, 113). Specifically looking at the descriptions of swords in the Ulster Cycle stories, Mallory $(1981,107)$ was able to show 'there is not a single sword type mentioned in the Ulster cycle that must be set to the Early Iron Age'. However he also affirmed that 'if the Ulster Tales reveal little about the archaeology of Iron Age Ulster, they ... do provide us with some idea of what life may have been like during the Iron Age and even some hint of those beliefs that the archaeologist is generally powerless to recover' (Mallory \& McNeill 1991, 170 ), so that it seems reasonable to suggest that it may have been the practice to name shields and swords in Iron Age Ireland. Whether or not such a suggestion is reasonable, it is of course very dangerous to use analogies from myth, whether it be Homeric epic, the Irish Táin or the Norse sagas, to reconstruct prehistoric reality, so I shall now use archaeological evidence to ask whether prehistoric weapons also could have an identity, indicated by a name or an anthropomorphic form or decoration.

\section{La Tène swords}

At least two late La Tène long swords are punchmarked with a personal name. A sword from Port(?), Canton Bern, Switzerland, datable to early in the second half of the first century BC, is stamped 'Korisios' in Greek script (Fig. 1; Wyss 1956; Livens 1972), whilst a sword from Zemplín (Grave 1, tumulus 8), Slovakia, dated perhaps as late as the end of the first century $\mathrm{BC} /$ beginning of the first century $\mathrm{AD}$, is marked V]TILICI[O in Latin letters (Pleiner 1993, 80, $97-8$, fig. 11). In neither case is it clear whose name is being referred to, and both the smith and the owner have been suggested (Livens 1972; Pleiner 1993, 48 n. 5; Wyss 1956), which would fit Barnes's (1972, col. 545) sword-name categories 1, 2 or 3 (cf. above). It is clear however from the foregoing discussion that in both cases the name could easily be that of the sword itself, in which case we might hypothesize that an identity is being assigned to the sword. It is worth noting that both the Port(?) and the Zemplín swords are described as being of good quality (Pleiner 1993, 65, metallographic analysis on pp. 97-8; Wyss 1956, 


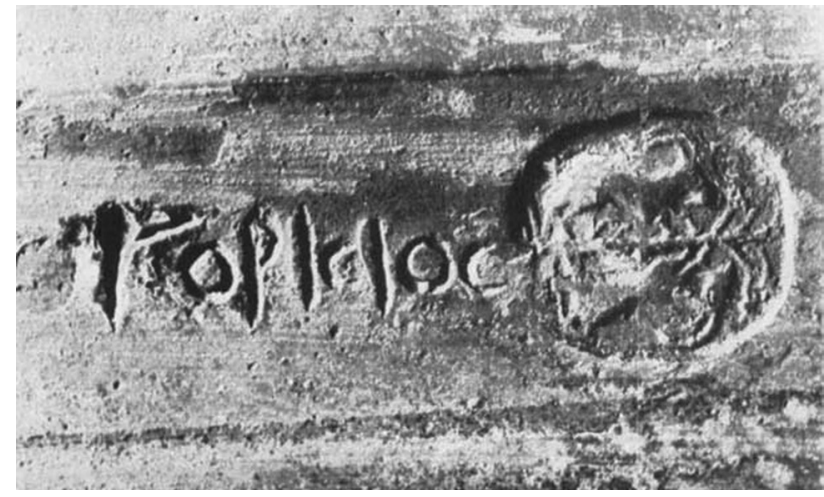

Figure 1. Stamp reading 'Korisios' in Greek script on a sword from Port(?) (Canton Bern, Switzerland; source: Wyss 1956, pl. VIIIB).

27) suggesting that well-made swords with fine blades were more likely to be attributed identities.

La Tène short swords with an anthropomorphic hilt (Figs. 2 \& 3; Clarke \& Hawkes 1955; Fitzpatrick 1996) are held to derive from central European Late Hallstatt antennae daggers (some of which have somewhat anthropoid hilts: Clarke \& Hawkes 1955, 204, fig. 1:3 \& 4). The La Tène anthropomorphic hilted short swords first appear in northern Italy in a Golasecca IIIA1 burial at Ca' Morta, Como (tomb VIII/1926: Negroni Catacchio 1971-72; De Marinis 1981, 56-62, tav. 30:3) dating to the second quarter of the fifthcentury $\mathrm{BC}$, and they continue in use over much of 'Celtic' Europe until the first century вс (and in Britain possibly into the first century $\mathrm{AD}$ ), with modifications in the shape of the handle but a remarkably similar design and consistent size. The earliest types are relatively schematic in their representation of the human form, but this becomes more naturalistic through time, especially from the second century вс. Moustaches on some of the faces indicate that the figures are male, and Fitzpatrick $(1996,374)$ argues that they may be divine, since, apart from heads, full-length human figures are rarely represented in Celtic art (Megaw \& Megaw 1989, 21). Fitzpatrick $(1996,376)$ notes that anthropomorphic hilted short swords are much rarer than Iron Age long swords, with only around 60-70 known; he argues that they were deposited in less than 1 per cent of all burials. Anthropomorphic hilted short swords are also depicted on Celtic coins (Allen 1980, 146, pls. 14:191 \& 33:502; Clarke \& Hawkes 1955, 214-15; De La Tour 1892, pl. XX:6941).

Hawkes (Clarke \& Hawkes 1955, 216) was not clear whether the anthropomorphic hilted short swords were 'felt' to be human, and wondered whether a divinity might be represented; others see them as talismanic (Petres 1979, 176). Although
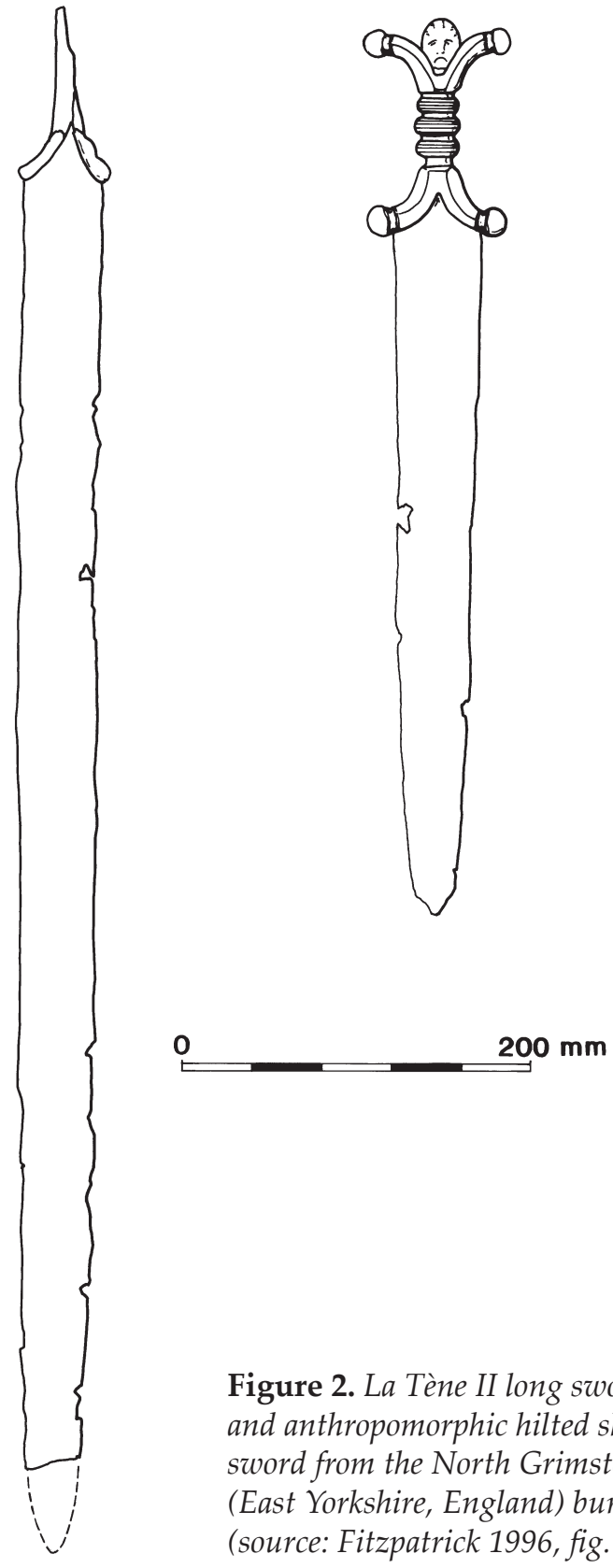

Figure 2. La Tène II long sword and anthropomorphic hilted short sword from the North Grimston (East Yorkshire, England) burial (source: Fitzpatrick 1996, fig. 1).

anthropomorphic hilted short swords have generally been seen to be markers of high status (Filip 1962, 103), there is not generally a correlation with rich burials (Fitzpatrick 1996, 377-8). Fitzpatrick argues that their short blades and small handles made them impracticable as weapons $(1996,376)$ and on the basis of the lunar (and perhaps solar) symbols recognized on nine examples of mid-late La Tène date (Fig. 3; Fitzpatrick 1996, 380-85) he posits that they may have had symbolic and ritual functions, particularly associated with counting time, perhaps being used to stab victims during human sacrifices (Diodorus Siculus 


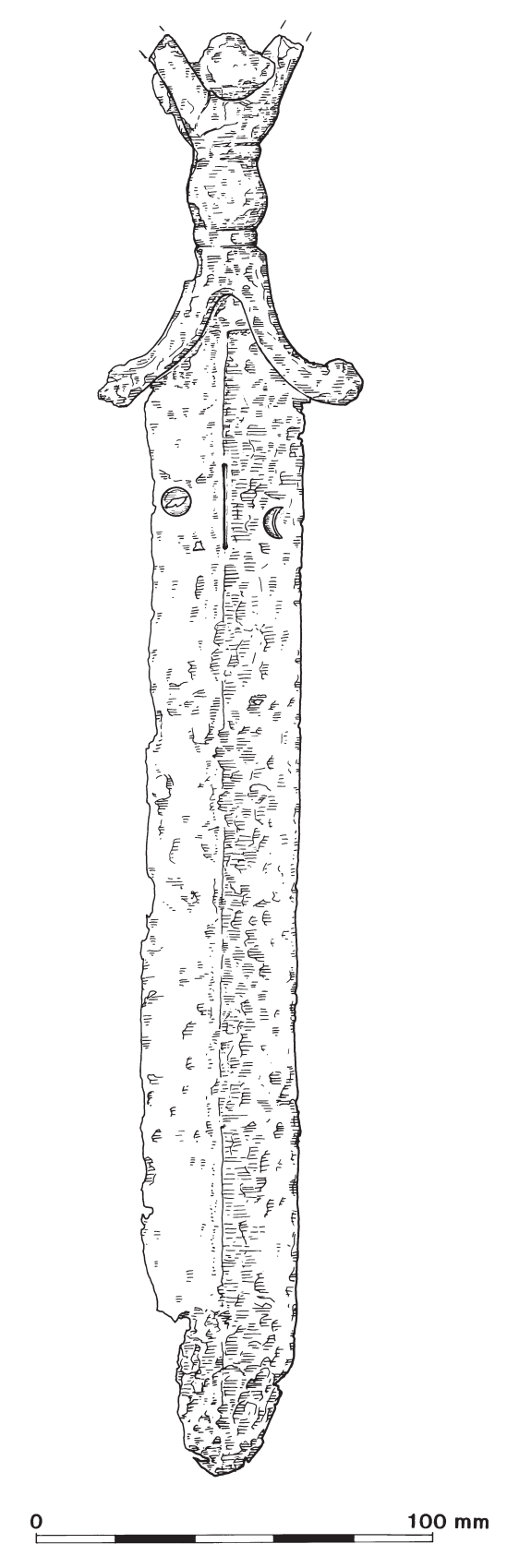

Figure 3. Anthropomorphic hilted short sword from Lysice (Moravia, Czech Republic), stamped with a vertical line on the rib and a circle and right facing crescent (source: Fitzpatrick 1996, fig.4).

V, 31, 2 tells us that such victims were stabbed with daggers by the Gauls) (Fitzpatrick 1996, 388-9).

Between the third and first centuries вс punchmarks, sometimes inlaid with gold or copper alloy, appeared on La Tène long swords (Fig. 4), some spears and also a small number of anthropomorphic hilted short swords. Drack (1954-55, 200-216) identified five

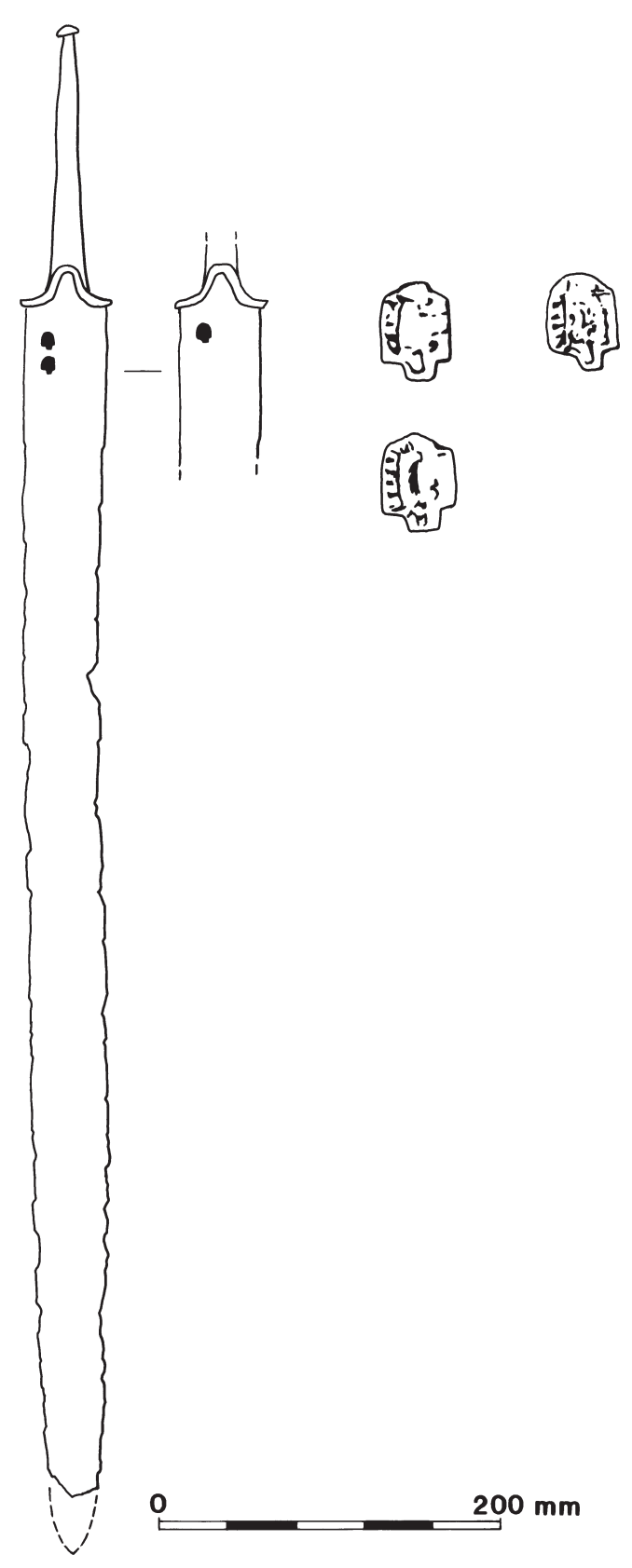

Figure 4. Long sword with three boar stamps, inlaid with gold, from Böttstein (Aargau, Switzerland; source: Fitzpatrick 1996, fig. 6).

classes of these stamps: 1 ) zoomorphic (generally a boar); 2) mixed (generally a horse and its rider); 3 ) astral; 4) anthropomorphic; and 5) others. Anthropomorphic punch-marks are the most common, followed by zoomorphic stamps. Vouga (1923, cols. 36-7) suggested that the stamped symbols might be property marks, or apotropaic, protecting the long sword and 
its user, or quality marks for special pieces, whilst for Petres $(1967-68,40)$ they were indicators of high prestige as they occur on a relatively low proportion of swords. However, as Fitzpatrick (1996, 379-80) points out, it is difficult to be sure of their actual prevalence, since La Tène sword blades and scabbards are not always well preserved, and corrosion means that it is difficult to assess the detail (and thus the degree of variability) of the punch-marks. Others have argued that since the stamps were applied by the blacksmith or armourer that they are maker's marks, in line with medieval practice, though some of the weapons on which they occur were of average quality, and it is not clear why some blades were stamped and the majority were not (Pleiner 1993, 65; Stead 2006, 49); this would fit with Barnes's (1972, col. 545) sword name category 3.

I would argue that the anthropomorphic hilts of the short swords and the anthropomorphic stamps found on some long swords, spears and short swords signal the identity or personhood attributed to the weapons. Whether or not the short swords were actually weapons, their form indicates that they symbolized weapons, and their anthopomorphic hilts seem to indicate the importance of their identity or personhood. It might even be suggested that in some cases a non-anthropomorphic stamp might indicate the sword's name, which would for example suggest that 'boar' (Fig. 4) was on occasion used to denote a sword in mid to late La Tène Europe, in the same way as 'snake' or 'wolf' was in the Nordic sagas (see above, Barnes's (1972, col. 546) sword-name category 10). Likewise the lunar or solar symbols may also have conferred identity (cf. Barnes's categories 10 or 11: 1972, col. 546). This identity may have been conferred at the moment of manufacture, setting stamped swords apart from those which were not chosen to bear stamps.

\section{Early Iron Age spearheads}

In early Iron Age central and southern Italy, weapons appear to be indicators of male status, and while swords were rare and therefore seem to indicate high social prestige, spearheads and javelin heads were the normal attribute of all or almost all young and adult men (Bietti Sestieri 2006, 507).

A probable high status grave assemblage from Cassino (Frosinone province), in central Italy, in the British Museum (Fig. 5:1; Bietti Sestieri 2006, 510-14, fig. 2; Bietti Sestieri \& Macnamara 2007, 127, cat. nos. 457-9), datable to the early phase of the early Iron Age (tenth-early ninth century вс), consists of a type Cumae sword and two spearheads with a conical socket and foliate blade, one of which is decorated with hatched triangles and meanders, circles and dots (cat. no. 458); its 'decoration creates the approximation of a human face and headdress' (Bietti Sestieri \& Macnamara 2007, 127). I would suggest that rather than a headdress we might prefer to see the crest of a helmet. Its length $(37 \mathrm{~cm})$ and workmanship indicate that it is a status symbol as well as a functional weapon (Bietti Sestieri 2006, 514).

Two similar spearheads are present in the collections of the British Museum, and may also be dated to the early phase of the early Iron Age. One has a provenance of Bari in Puglia, southeast Italy (Fig. 5:2). Bietti Sestieri and Macnamara (2007, 122, cat. no. 387) who publish it, suggest that ' $[t]$ he decoration creates the approximation of a human face'. The circles roughly represent the eyes and the mouth, whilst the central facet suggests a nose. It is relatively long $(33 \mathrm{~cm})$. The other spearhead (Fig. 5:3), of the same type, came from the private collection of Count Milano, and is without provenance, but it may be generically assigned to the early Iron Age (Bietti Sestieri \& Macnamara 2007, 122, cat. no. 388). Here the decoration again shows a human face, represented by circles, with a headdress or helmet-crest indicated by the hatched triangles on the blade. It is $29.7 \mathrm{~cm}$ long. These two spearheads are smaller than the example from Cassino, and their decoration and workmanship are less refined (Bietti Sestieri 2006, 516).

Bietti Sestieri and Macnamara comment on these three spears $(2007,23)$ that 'the human face probably is meant to add a magical or supernatural power to the spear'. As in the case of the La Tène swords discussed above, I would add that the face decoration assigns an identity, or perhaps even spiritual persona with its own specific agency, to the spears.

A miniature spearhead, also present in the collections of the British Museum, probably comes from a male cremation burial from the Campania region of Italy and is also datable to the early phase of the early Iron Age (Bietti Sestieri 2006, 518; Bietti Sestieri \& Macnamara 2007, 122, cat. no. 389). It has a decoration suggesting two eyes and a headdress (Bietti Sestieri 2006,518 ) or helmet-crest.

Bietti Sestieri (2006, 518-25, figs. 4-9) has shown that the face and headdress iconography continues on spearheads of the typological series in the second phase of the early Iron Age (ninth-eighth century вс) in central and southern Italy, with examples from Pontecagnano (Salerno), contrada La Rota (Candidoni, Reggio Calabria), Castellace (Oppido Mamertina, Reggio Calabria), Cairano (Avellino), Sala Consilina (Salerno), Marsico Nuovo (Potenza), Amendolara (Cosenza), Bari, Naples and perhaps Caracupa (Sermoneta, Latina). Though the decora- 


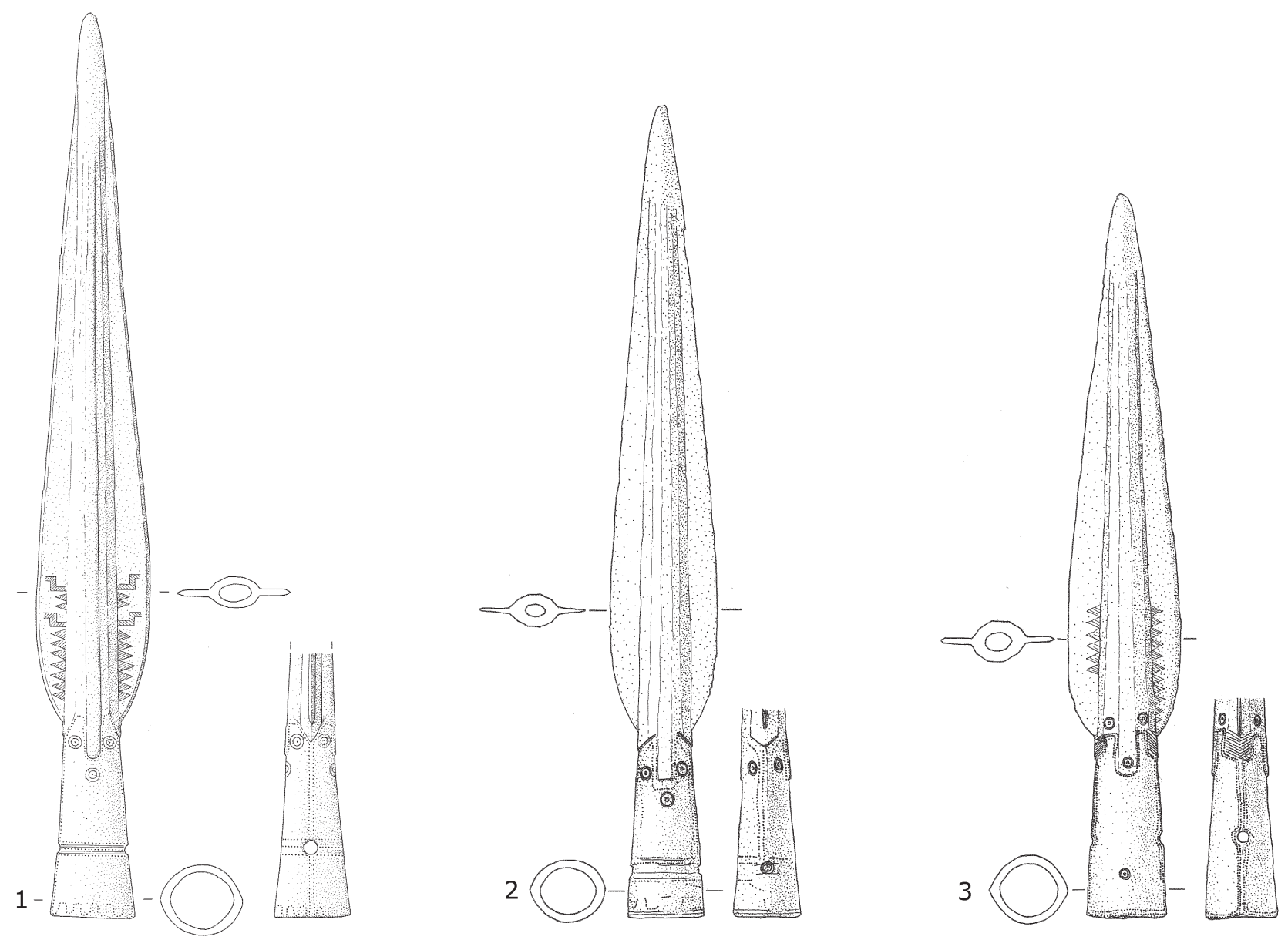

Figure 5. Italian Early Iron Age spearheads with face decoration: 1. Cassino (Frosinone; source: Bietti Sestieri \& Macnamara 2007, pl. 103, cat. no. 458); 2. Bari (source: Bietti Sestieri \& Macnamara 2007, pl. 81, cat. no. 387); 3. From the collection of Count Milano (source: Bietti Sestieri \& Macnamara 2007, pl. 81, cat. no. 388).

tion becomes progressively more abstract, she argues that it is likely to have preserved its meaning (Bietti Sestieri 2006, 519).

Bietti Sestieri $(2006,529)$ suggests that the richlydecorated spearheads of this series are rare and likely to be markers of status, though she notes that the decorative motif is unlikely to have been highly visible. Interestingly, further north, in the contemporary male graves of Villanovan central-northern Italy, the face and headdress iconography does not occur. This may be because there seems to be a general ritual prohibition on the deposition of arms in that area; certainly, where spearheads are found (in some highstatus burials), they are of a different type and do not bear face decoration (Bietti Sestieri 2006, 525).

Some of the central and south Italian spearheads illustrated by Bietti Sestieri have perforations in the lower part of their blade (2006, figs. 4:3 - La Rota; 5:1 Castellace; 5:2 - Pontecagnano; 7:2 - Cairano; 7:3 - Sala
Consilina); these may perhaps be part of the decorative scheme and represent the eyes of the spearhead.

Sauerbrunn/Boiu series swords

In a 1966 paper, 'The origins of the flange-hilted sword of bronze in Continental Europe', J.D. Cowen argued that the twin spiral motif on middle Bronze Age type Boiu swords was intended to indicate '... a pair of eyes and maybe a brow over them as well. These would then be the eyes of the sword itself, or rather of the spirit within it ...' (Cowen 1966, 294). He adds that what he calls the 'magical significance' of the design would account for its 'consistency ... over a wide field for a considerable period' (Cowen 1966, 294). Cowen then goes on to argue that a rapier from 'Hungary' (which he assigned to his middle Bronze Age type Sauerbrunn) carries a depiction of the whole body of the 'spirit, or daemon, dwelling in the sword' (Cowen 1966, 294). Figure 6:1 clearly shows its 

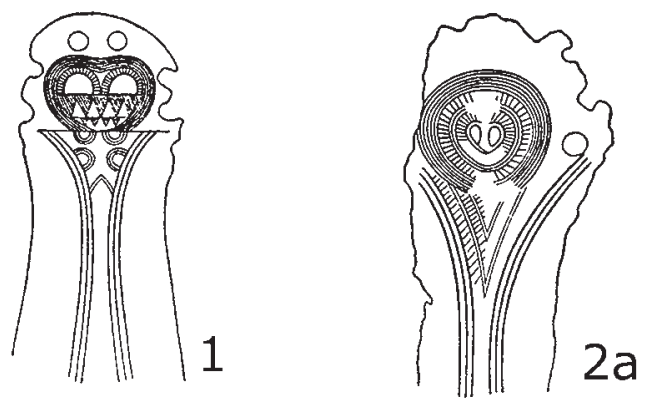

outstretched arms, body and legs, and its insect-like eyes and serrated teeth set in a large head. I would add that the sword from Hochstadt, also illustrated by Cowen (1966, fig. 3:7 \& 8; assigned to his type Sauerbrunn), shows a similar insect-eyed face, and the faces depicted on either side of the blade can be seen in Figure 6:2a and $b$.

Swords of the Sauerbrunn/Boiu series have a distribution with two focuses, in northeastern Italy and the Carpathian basin, with outliers in south Germany, Poland, Austria, Slovenia, Croatia and Romania. Neumann (2009) lists 99 swords of the series, though some of his attributions are controversial (cf. Cupito 2006, 66-7, 71-82, not cited by Neumann 2009). As is often the case, there is also disagreement about the detail of their classification and there have been many typological schemes since Cowen (e.g. Bianco Peroni 1970, 8-13, 38-51; Kemenczei 1988, 36-42; Schauer 1971, 20-23, 94-7), but recent studies tend to follow Cowen's (1966) system (Cupitò 2006, 66-7, 71-82; De Marinis \& Salzani 2005, 393-5, 397-403; Neumann 2009). A number of hypotheses have been put forward for the origin of the decoration which characterizes these swords and these are summarized by Neumann $(2009,100)$.

Examining the publications of the 99 Sauerbrunn/Boiu swords listed by Neumann (2009, 112-14), I found that at least 46 have decoration that resembles a face. This face decoration is found in both distribution foci, in northeastern Italy and the Carpathian basin, but also on swords from outlying findspots, such as in south Germany or Romania. In 21 cases the decoration is missing or partially worn so that it is impossible for me to ascertain the original motif and in two further cases (Neumann's nos. 80 and 81 from the River Piave at Colfosco di Sussegana, Treviso, northern Italy) there is no illustration published to allow the decoration to be assessed.

Forty-six of the swords of the Sauerbrunn/Boiu series were found in northern Italy and twenty-five of them have a face-like motif. The large (456 inhumation burials and 61 cremation burials) cemetery of Olmo di Nogara (Verona: Salzani 2005) provides an excellent

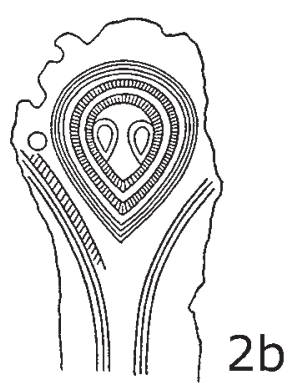

Figure 6. Cowen's illustrations of swords with face decoration of his type Sauerbrunn: 1. 'Hungary' (source: Cowen 1966, fig. 3:9); 2a. Hochstadt (Germany), face $A$ and $2 b$. face $B$ (source: Cowen 1966, fig. 3:7 \& 8).

illustration of their prevalence and significance. At Olmo di Nogara swords are present in 43 high-status male tombs (out of a total of 149 burials identified osteologically as male), and 19 (Neumann 2009) or 20 (De Marinis \& Salzani 2005, 393-5, 397-403; Cupitò 2006, 66-7, 71-82, figs. 29, 31-6) of these may be classified in the Sauerbrunn/Boiu series. Sixteen of the Sauerbrunn/Boiu swords found at Olmo di Nogara show face-type decoration (Fig. 7): in tombs 26, 31, 33, $35,40,50,54,88,93,95,131,153,201,389,442$ and 486 (Salzani 2005, tav. IV-VIII, X, XI, XIV, XV, XX, XXX, XXXVII \& XXXIX). It should be noted that as with the Iron Age spearheads discussed above, in some cases the decoration tends towards the abstract and can be recognized as indicating a face only by reference to, and comparison with, the more figurative examples.

\section{Discussion}

We must ask ourselves a number of questions. In the first place, whether there are any alternative hypotheses to explain this decoration on Iron Age swords and spearheads and middle Bronze Age swords, and secondly, whether there is a difference between weapons with names, and weapons with anthropomorphic hilts or faces on them, particularly where those faces are schematic. Finally, we may ask why such decoration is not present uniformly, but only on certain types and on certain examples of those types.

As regards alternative hypotheses to explain the decorative motif, it is certainly true that human beings have a tendency to interpret unstructured visual stimuli in meaningful ways (Wertheimer 1923). In particular we are prone to 'see' faces or eyes for instance in wood or in patterns on textiles or wallpaper, when these materials' stimulus structure have face-like properties (a phenomenon called pareidolia: Hadjikhani et al. 2009). It might be easy to over-interpret stimuli that may seem to depict faces. But when looking at the spearheads and swords illustrated in this article, the faces are very striking (see Figs. 5, $6 \& 7$ ). It is clearly impossible to demonstrate conclusively that faces are meant, but it does seem evident. 

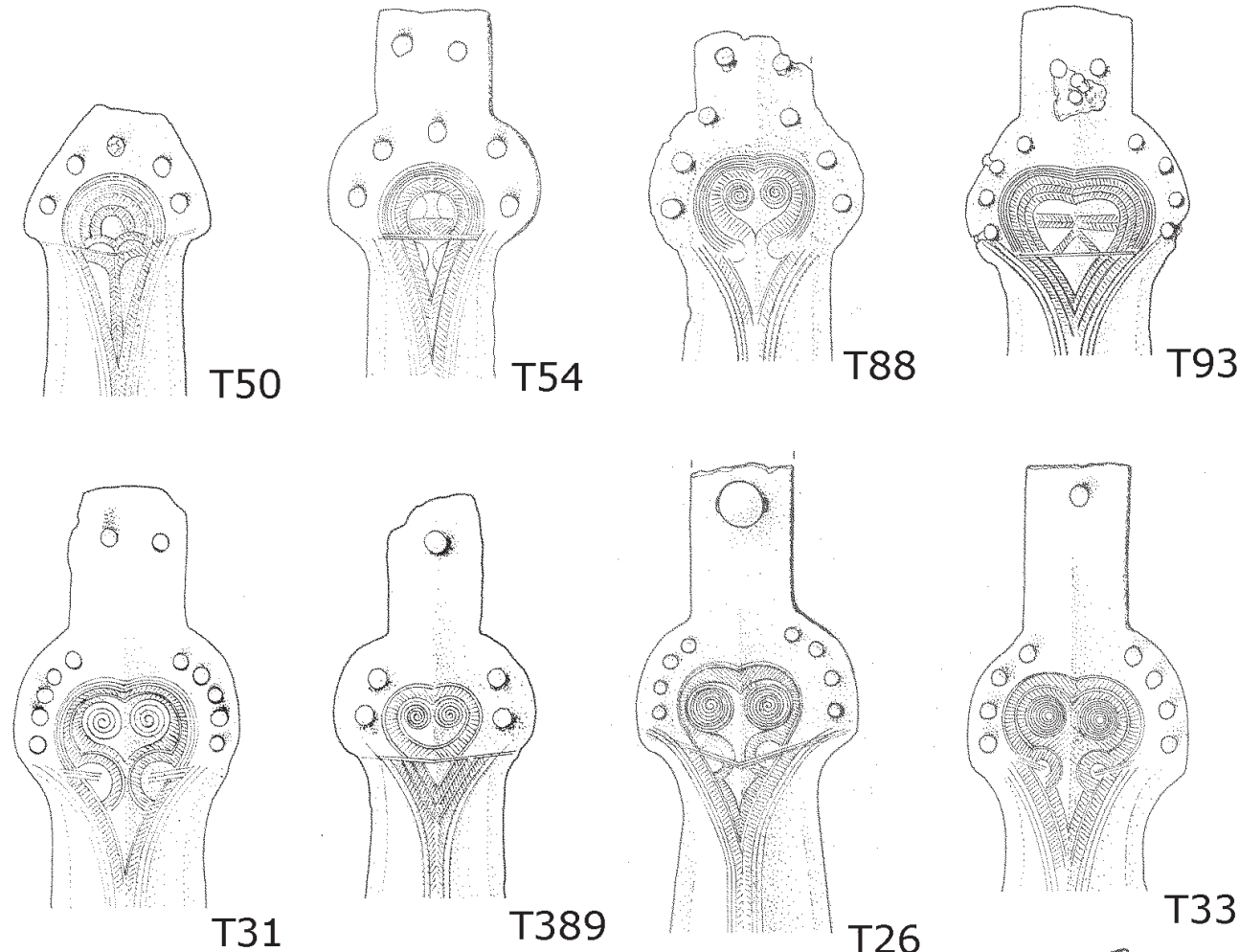

T31
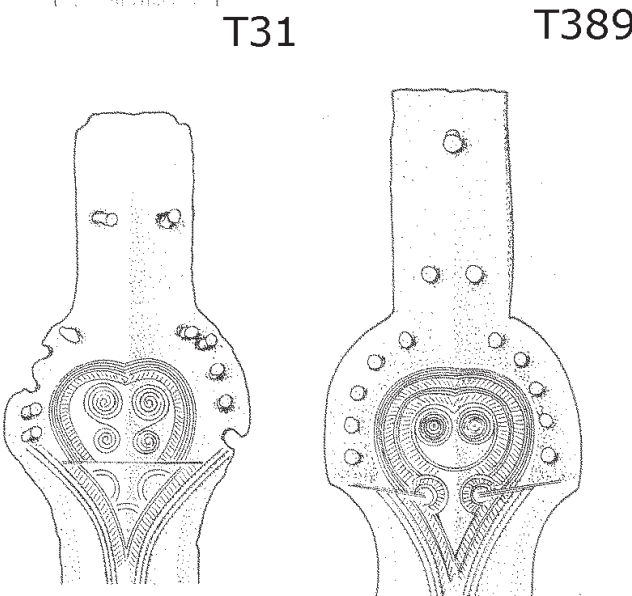

T95

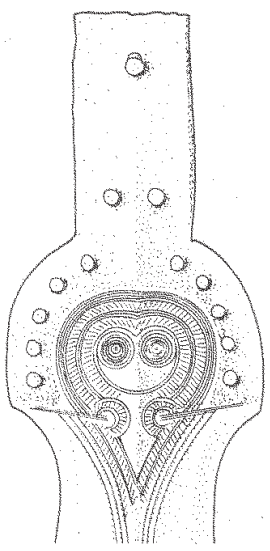

T33

Figure 7. Middle Bronze Age swords from the Olmo di Nogara (Verona, Italy) cemetery with face decoration (after Salzani 2005, tav. IVVIII, X, XI, XIV, XV, $X X, X X X, X X X V I I$, $X X X I X)$.
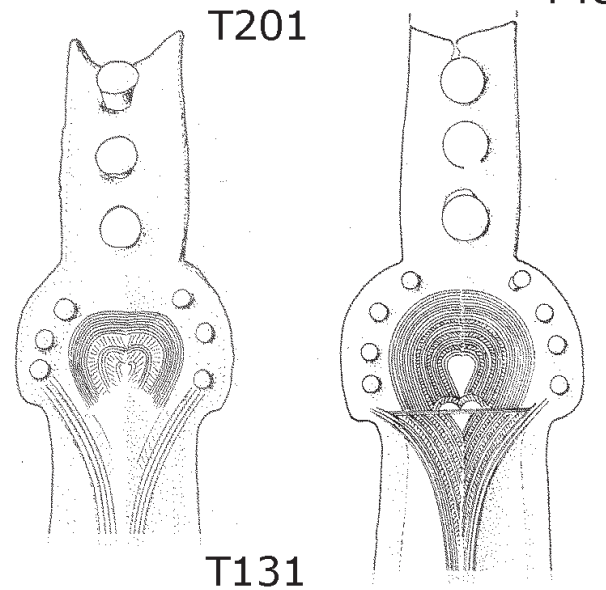

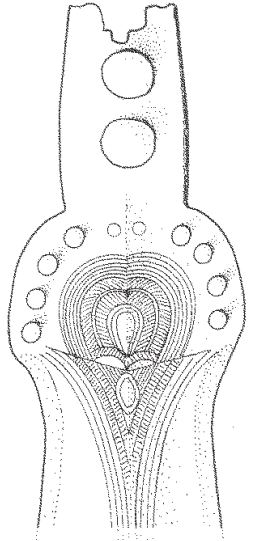

T40

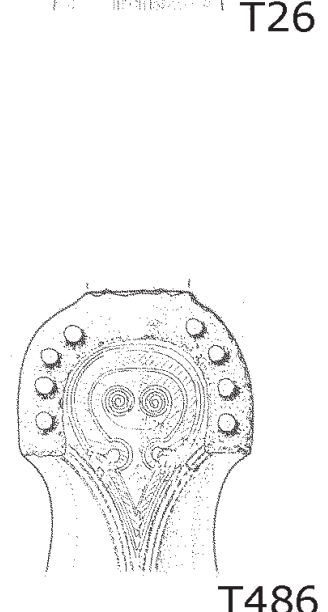

T153

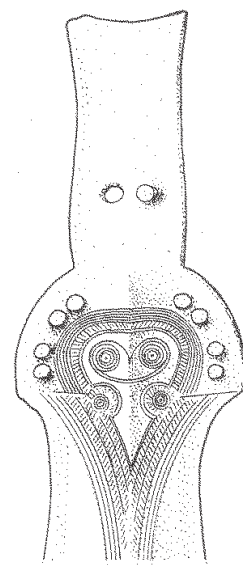


It could be argued that whereas names are individual, faces may be more generic, just indicating a human or divine quality, but not necessarily an individual identity. However, one of the most striking aspects of the depictions of faces on early Iron Age spearheads or Bronze Age Sauerbrunn/Boiu series swords is their variation. As can be seen in Figures 5,6 and 7, the faces are in fact very different. It is my contention indeed that this very variability is a strong argument in favour of their indicating individual identity. The faces mark them out as different from the artefacts of the same type that do not bear faces (and this distinction is likely to have been conferred from the moment of manufacture).

That faces occur on both sides of the blades of the early Iron Age spearheads depicted in Figure 5, may emphasize their all-seeing nature, so that they literally - as Williams puts it when discussing pervasive eye decoration on material from the early seventh-century AD ship-burial under Mound 1 at Sutton Hoo (Suffolk, England) - had eyes in the back of their head (Williams 2011, 108).

The fact that faces are limited to certain types of swords and spearheads, and to certain sub-groups of those types, needs to be explained. It may be that all weapons were considered to have an identity, but that only some carried explicit figurative decoration. Alternatively it may be that particular weapons only were considered to have such a quality, and that this was a result of a specific event in their biography, in this case one would expect the decoration that denoted that identity to have been applied later in the life of the artefact (i.e. not at manufacture). In this connection, we may refer again to the Norse sagas, where Barnes (1972, cols. 544-5) argues that not all swords had names and that it seems to have been the custom to give a sword a name after it had proved itself in some way: thus a sword or a spearhead is likely to have acquired an identity where it had a significant biography. A further possibility is that the face and eye decoration may be an explicit reference to such biographical event in the life of a mythical or known weapon of a particular type or provenance: this may explain why in the case of the weapons discussed in this paper, the anthropomorphic and face representations seem to have been applied at manufacture (cf. Pleiner 1993, 65 for the punch-marks on La Tène weapons). Finally, it should be noted that not only swords and spearheads have anthropomorphic decoration: human heads increase 'in frequency and realism in the art of the late Iron Age' (Megaw \& Megaw 1989, 164) and also occur on other artefacts, such as phalerae (disks), linch-pins and cauldrons (Megaw \& Megaw 1989, figs. 256-7, 265, 282-6). Various explanations for this decoration are possible, and in some cases it may again signal the attribution of identity to the artefact, but it may also have talismanic or apotropaic functions.

Much of the archaeological evidence that I have adduced in this article for the ascription of identity to artefacts - such as stamping and anthropomorphic decoration - corresponds to Yvonne Marshall's (2008) concept of 'inscribed' objects - they are artefacts that 'have meaning incorporated into their body in the course of their making'. In this case ' $[\mathrm{m}]$ eaning is prescribed in advance of social action. An attempt is made to materially, and thereby socially, fix meaning.' (Marshall 2008, 64). On the other hand, unless they were similarly 'inscribed', the swords described in the myth cycles or epic outlined above correspond to her category of 'lived' objects - that 'acquire meaning in the context of social action'; this meaning is 'contextual and may change at any time' (Marshall 2008, 63). Since these swords with names and identities do not necessarily have stamping or anthropomorphic decoration, such 'lived' meaning may be difficult to demonstrate archaeologically. It may, however, be documented by evidence of an extended use-life, for example indicated by repair of an artefact. Thus, the scabbard of the Kirkburn (East Yorkshire, England) sword shows signs of several repairs (Stead 2006, 184-5, figs. 85-7; Giles 2008, 61), just as important swords like Sigurdur's Gramr or Grásída were reforged in the Norse sagas (see above).

\section{Conclusion}

I have shown that in medieval epic, the Irish Táin and the Norse sagas weapons may have names and supernatural powers and capacities. On occasion such weapons had complex biographies. These characteristics are also attested historically and weapon names written in runes are also known. Early northern European literature attests that weapons could have an identity.

It is dangerous to use analogies from myth to reconstruct prehistoric reality and my exploration of the identity of prehistoric weapons has been firmly based on archaeological evidence, from both the Bronze and Iron Ages. Two late La Tène long swords are punch-marked with a personal name, which may be that of the manufacturer or owner, but may be that of the weapon itself. The anthropomorphic hilts of La Tène short swords - which may have had a symbolic or ritual rather than combat function - signal their identity or personhood as do anthropomorphic stamps on swords and spears; other punch-marks may indicate the weapon's name. Likewise, faces on early 
Iron Age spearheads from central and southern Italy indicate the identity - perhaps even the personhood - of the spears. Many years ago, Cowen $(1966,294)$ suggested that the decoration on swords of the Sauerbrunn/Boiu series represented 'the eyes of the sword, or rather of the spirit within it ...'. My wide-ranging discussion suggests that Cowen's intuition was both plausible and credible, and that in prehistoric Europe, as in later periods, both swords and spearheads could have some sort of identity, and it may have been believed that they were indwelt by spirits or daemons.

Does this have any consequences? If we accept that there was a belief that some Bronze Age Sauerbrunn/Boiu series swords, Italian early Iron Age spearheads and La Tène swords and spears had an identity, or indeed an in-dwelling spirit, like those of the medieval myths and epic, an identity that might relate to their biographies, then they might have been conserved as heirlooms or exchanged as prestige gifts for much longer than is generally assumed. Such practices are difficult to document archaeologically, because we generally date artefacts on the basis of their associations, but they have been argued for weapons circulating in Anglo-Saxon society (Härke 2000) and also for the sword in tomb 42 at Olmo di Nogara and the type Sauerbrunn sword from Sauerbrunn, Burgenland, Austria, by analogy with Odysseus' boars' tusk helmet (Iliad 10, 260-71) which was passed across the generations by heroic giftexchange and inheritance (Cupitò 2005, 242). Likewise the sword Ættartangi passed down the generations and appears in both Vatnsdoela Saga and Grettis Saga (Ellis Davidson 1962, 171-2) and Barnes comments that the Norse name for this sword is a name which denotes that the sword was meant to stay in a family for many generations (1972, col. 545). These examples suggest that some weapons may have circulated a long time after their manufacture (cf. Whitley 2002), which in turn may have serious implications for the use of such weapons in typological dating schemes and for our understanding of their deposition in tombs. Artefacts which because of their special identity had acquired a complex biography and to which stories had become attached, concerning for example their previous owners or their prowess in combat, are likely to have had specific roles in social relations, and this special, powerful, identity may have conferred on them a 'guardian spirit' function when they were deposited.

\section{Acknowledgements}

I am greatly indebted for their invaluable help with the Nordic examples to Judith Jesch and Torill Christine Lindstrøm (who also advised me on the psychological phenomenon of pareidolia). Ruth Whitehouse and Jody Joy kindly commented on previous versions of the paper. Andrew Fitzpatrick generously provided his original artwork for Figures 2-4. Permission to reproduce figures was provided by Antiquity Publications, the British Museum Press, the Prehistoric Society and Luciano Salzani. Earlier versions of this paper were given at the session on 'New approaches on studying weaponry of the European Bronze Age' (organized by Marion Uckelmann and Marianne Mödlinger) at the 15th Annual Meeting of the European Association of Archaeologists in Riva del Garda, Italy, 15-20 September 2009 , at a seminar on prehistoric Italy held at the University of Nottingham on 17 February 2010, and at a seminar at the University of Padua, Italy, 17 June 2010; I am very grateful to all those who commented in the discussion on those occasions. This paper was revised after refereeing at the Römisch-Germanische Kommission in Frankfurt: I am very grateful to the Director, Svend Hansen, for hospitality and bibliographic advice. None of the above have any responsibility for any errors or omissions in the paper.

Mark Pearce
Department of Archaeology
University of Nottingham
University Park
Nottingham
NG7 2RD
UK
ark.pearce@nottingham.ac.uh

\section{References}

Aitchison, N.B., 1987. The Ulster Cycle: heroic image and historical reality. Journal of Medieval History 13, 87-116.

Allen, D.F., 1980. The Coins of the Ancient Celts, ed. D. Nash. Edinburgh: Edinburgh University Press.

Barnes, M., 1972. Sverdnavn, in Kulturhistorisk leksikon for nordisk middelalder fra vikingetid til reformationstid, vol. 17. Copenhagen: Rosenkilde og Bagger, cols. 544-7.

Barnes, M., 1982. Våpennavn, in Kulturhistorisk leksikon for nordisk middelalder fra vikingetid til reformationstid, vol. 20. 2nd edition. Copenhagen: Rosenkilde og Bagger, cols. 282-5.

Bianco Peroni, V., 1970. Le spade nell'Italia Continentale. (Prähistorische Bronzefunde IV, 1.) Munich: Beck.

Bietti Sestieri, A.M., 2006. Fattori di collegamento interregionale nella prima Età del Ferro: indizi di un'ideologia condivisa, legata alle armi, dal Lazio meridionale alla Puglia. Rivista di Scienze Preistoriche 56, 505-33.

Bietti Sestieri, A.M. \& E. Macnamara, 2007. Prehistoric Metal Artefacts from Italy (3500-720BC) in the British Museum. (Research Publication 159.) London: British Museum.

Bradley, R., 1990. The Passage of Arms: an Archaeological Analysis of Prehistoric Hoards and Votive Deposits. Cambridge: Cambridge University Press.

Clarke, R.R. \& C.F.C. Hawkes, 1955. An iron anthropoid sword from Shouldham, Norfolk with related 
continental and British weapons. Proceedings of the Prehistoric Society 21, 198-227.

Cowen, J.D., 1966. The origins of the flange-hilted sword of bronze in continental Europe. Proceedings of the Prehistoric Society 32, 262-312.

Cupitò, M., 2005. La necropoli dell'età del bronzo a Gambaloni di Povegliano. Rilettura e reinterpretazione dei dati ottocenteschi alla luce dei nuovi documenti d'archivio, in Archeologia e idrografia del Veronese a cent'anni dalla deviazione del fiume Guà (1904-2004). Il Museo Archeologico di Cologna Veneta e le prime ricerche archeologiche nella pianura veronese, eds. G. Leonardi \& S. Rossi. (Saltuarie dal laboratorio del Piovego 6.) Cologna Veneta: Ambrosini, 197-265.

Cupitò, M., 2006. Tipocronologia del Bronzo medio e recente tra l'Adige e il Mincio sulla base delle evidenze funerarie. (Saltuarie dal laboratorio del Piovego 7.) Padua: Imprimitur.

De Marinis, R., 1981. Il periodo Golasecca III A in Lombardia. Studi Archeologici 1, 41-303.

De Marinis, R.C. \& L. Salzani, 2005. Tipologia e cronologia dei materiali, in La necropoli dell'età del Bronzo all'Olmo di Nogara, ed. L. Salzani. (Memorie II serie, Sezione Scienze dell'Uomo 8.) Verona: Museo Civico di Storia Naturale di Verona, 391-448.

Ditmas, E.M.R., 1966. The Curtana or Sword of Mercy. Journal of the British Archaeological Association 29 (third series), 122-33.

Dobres, M.-A., 2000. Technology and Social Agency. Oxford: Blackwell.

Drack, W., 1954-55. Ein Mittellatèneschwert mit drei Goldmarken von Böttstein (Aargau). Zeitschrift für Schweizerische Archäologie und Kunstgeschichte 15, 193-235.

Ellis Davidson, H.R., 1962. The Sword in Anglo-Saxon England: Its Archaeology and Literature. Oxford: Clarendon Press.

Filip, J., 1962. Celtic Civilization and its Heritage. Prague: New Horizons. Publishing House of the Czechoslovak Academy of Sciences.

Fitzpatrick, A.P., 1996. Night and day: the symbolism of astral signs on later Iron Age anthropomorphic short swords. Proceedings of the Prehistoric Society 62, 373-98.

Giles, M., 2008. Seeing red: the aesthetics of martial objects in the British and Irish Iron Age, in Rethinking Celtic Art, eds. D. Garrow, C. Gosden \& J.D. Hill. Oxford: Oxbow Books, 59-77.

Gosden, C. \& Y. Marshall, 1999. The cultural biography of objects. World Archaeology 31(2), 169-78.

Hadjikhani, N., K. Kveraga, P. Naik \& S.P. Ahlfors, 2009. Early (M170) activation of face-specific cortex by facelike objects. NeuroReport 20(4), 403-7.

Härke, H., 2000. The circulation of weapons in Anglo-Saxon society, in Rituals of Power: from Late Antiquity to the Early Middle Ages, eds. F. Theuws \& J.L. Nelson. Leiden: Brill, 377-99.

Hatto, A.T., 1969. The Nibelungenlied, trans. A.T. Hatto. Harmondsworth: Penguin.

Holmes, M. \& H.D.W. Sitwell, 1972. The English Regalia: Their History, Custody and Display. London: Her Majesty's Stationery Office.
Jackson, K.H., 1964. The Oldest Irish Tradition: a Window on the Iron Age. (The Rede Lecture 1964.) Cambridge: Cambridge University Press.

Kemenczei, T., 1988. Die Schwerter in Ungarn I (Griffplatten-, Griffangel- und Griffzungenschwerter). (Prähistorische Bronzefunde IV, 6.) Munich: Beck.

Kinsella, T., 1969. The Táin: Translated from the Irish Epic Táin Bó Cuailnge. Dublin: Dolmen Press. [Reprinted Oxford: Oxford University Press, 1970.]

Kopytoff, I., 1986. The cultural biography of things: commoditization as process, in The Social Life of Things: Commodities in Cultural Process, ed. A. Appadurai. Cambridge: Cambridge University Press, 64-91.

Krause, W., 1966. Die Runeninschriften im älteren Futhark. (Abhandlungen der Akademie der Wissenschaften in Göttingen, Philologisch-Historische Klasse; Dritte Folge, 65.) Göttingen: Vandenhoeck und Ruprecht.

Kristiansen, K., 2002 The tale of the sword - swords and swordfighters in Bronze Age Europe. Oxford Journal of Archaeology 21(4), 319-32.

De La Tour, H. , 1892. Atlas de monnaies gauloises. Paris: Plon, Nourrit et Cie. [Reprinted Lund: Humphries, 1965.]

Livens, R.G., 1972. Who was Korisios? Antiquity 46(181), 56-7.

Mallory, J.P., 1981. The sword of the Ulster Cycle, in Studies in Early Ireland: Essays in Honour of M.V. Duignan, ed. B.G. Scott. Belfast: Association of Young Irish Archaeologists, 99-114.

Mallory, J.P. \& T.E. McNeill, 1991. The Archaeology of Ulster from Colonization to Plantation. Belfast: The Institute of Irish Studies, The Queen's University of Belfast.

Marshall, Y., 2008. The social lives of lived and inscribed objects: a Lapita perspective. Journal of the Polynesian Society 117(1), 59-101.

Megaw, M.R. \& J.V.S. Megaw, 1989. Celtic Art: from its Beginnings to the Book of Kells. London: Thames and Hudson.

Negroni Catacchio, N., 1971-72. Spade con impugnatura pseudo-antropoide nell'area della cultura di Golasecca. Rapporti tra il La Tène e il Golasecca III A. Sibrium 11, 113-31.

Neumann, D., 2009. Bemerkungen zu den Schwertern der Typenfamilie Sauerbrunn-Boiu-Keszthely, in Alpen, Kult und Eisenzeit: Festschrift für Amei Lang zum 65. Geburtstag, eds. J.M. Bagley, C. Eggl, D. Neumann \& M. Schefzik. (Internationale Archäologie: Studia honoraria 30.) Rahden/Westf.: Leidorf, 97-114.

Pearce, M., 2007. Bright Blades and Red Metal: Essays on North Italian Prehistoric Metalwork. (Specialist Studies on Italy 14.) London: Accordia Research Institute.

Petres, É.F., 1967-68. Zum Problem der gestempelten La Tène-Zeitlichen Schwerter. Alba Regia. Annales Musei Stephani Regis 8-9, 35-42.

Petres, É.F., 1979. Some remarks on anthropoid and pseudoanthropoid hilted daggers in Hungary, in Les mouvements celtiques du $V^{e}$ au $I^{\text {er }}$ siècle avant notre ère: Actes du XXVIII colloque organisé à l'occasion du $I X^{e}$ Congrès International des Sciences Préhistoriques et Protohistoriques, Nice, le 19 septembre 1976, eds. P.-M. Duval \& V. Kruta. Paris: Editions du Centre National 
de la Recherche Scientifique, 171-8.

Pleiner, R., 1993. The Celtic Sword, with contributions by B.G. Scott. Oxford: Clarendon Press.

Salzani, L., 2005. La necropoli, in La necropoli dell'età del Bronzo all'Olmo di Nogara, ed. L. Salzani. (Memorie II serie, Sezione Scienze dell'Uomo 8.) Verona: Museo Civico di Storia Naturale di Verona, 9-388.

Schauer, P., 1971. Die Schwerter in Süddeutschland, Österreich und der Schweiz I (Griffplatten-, Griffangel- und Griffzungenschwerter). (Prähistorische Bronzefunde IV, 2.) Munich: Beck.

Stead, I.M., 2006. British Iron Age Swords and Scabbards. London: British Museum Press.

Vinaver, E. (ed.), 1971. Malory: Works. 2nd edition. Oxford: Oxford University Press.

Vouga, P., 1923. La Tène: Monographie de la station publiée au nom de la Commission des Fouilles de la Tène. Leipzig: Karl W. Hiersemann.

Wertheimer, M., 1923. Untersuchungen zur Lehre von der Gestalt. Psychologische Forschung 4, 301-50.

Whitley, J., 2002. Objects with attitude: biographical facts and fallacies in the study of Late Bronze Age and Early Iron Age warrior graves. Cambridge Archaeological Journal 12(2), 217-32.

Williams, H., 2011. The sense of being seen: ocular effects at Sutton Hoo. Journal of Social Archaeology 22(1), 99-121.

Wyss, R., 1956. The sword of Korisios. Antiquity 30(117), 27-8.

\section{Author biography}

Mark Pearce is Associate Professor in Archaeology at the University of Nottingham. He specializes in north Italian prehistory, particularly early copper metallurgy and mining and the early Neolithic. He is author of Bright Blades and Red Metal: Essays on North Italian Prehistoric Metalwork, Il territorio di Milano e Pavia tra Mesolitico e Prima età del Ferro: Dalla carta archeologica alla ricostruzione del paesaggio and Materiali preistorici: Cataloghi dei Civici Musei di Pavia, I. He recently co-edited The Death of Archaeological Theory? and Ligurian Landscapes: Studies in Archaeology, Geography and History. 


\section{CAMBRIDGE JOURALS}

\section{The Classical \\ Review}

Published for The Classical Association

\section{Editor}

Neil Hopkinson, Trinity College, Cambridge, UK

Roger Rees, University of St Andrews, UK

The Classical Review publishes informative reviews from leading scholars on new work covering the literatures and civilizations of ancient Greece and Rome. Publishing over 300 high quality reviews and 100 brief notes every year, The Classical Review is an indispensable reference tool, essential for keeping abreast with current classical scholarship.

\section{Price information}

is available at: http://journals.cambridge.org/car

\section{Free email alerts}

Keep up-to-date with new material - sign up at http://journals.cambridge.org/alerts

For free online content visit: http://journals.cambridge.org/car

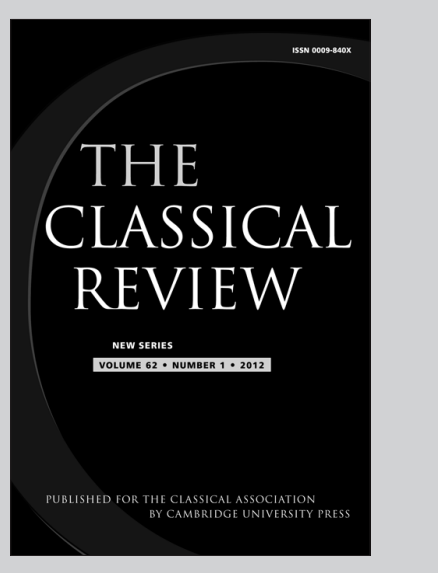

The Classical Review is available online at: http://journals.cambridge.org/car

To subscribe contact Customer Services

\section{in Cambridge:}

Phone $+44(0) 1223326070$

Fax $+44(0) 1223325150$

Email journals@cambridge.org

in New York:

Phone +1 (845) 3537500

Fax +1 (845) 3534141

Email

subscriptions_newyork@cambridge.org 